\title{
Cobalamin malabsorption due to a dysfunctional intrinsic factor
}

\author{
JEANNE DROUIN, MD, FRCPC, NADIA MIKHAEL, MD, FRCPC
}

\begin{abstract}
An 18-year-old French Canadian student presenting with a severe normocytic anemia, had undetectable serum cobalamin but normal gastric acidity and no evidence of generalized malabsorption. The gastric juice contained a normal quantity of intrinsic factor. Serum anti-intrinsic factor blocking antibodies were not present. Absorption of radiolabelled cobalamin given orally in the Schilling test was decreased but this was corrected by using hog intrinsic factor. Patient gastric juice bound cobalamin normally but did not promote uptake of this vitamin by homogenates of guinea pig intestinal mucosa. A family study showed normal cobalamin absorption for all tested subjects, as well as two $\propto$-hemoglobin gene deletions in the father and a single $\propto$-gene deletion in the patient. The cobalamin malabsorption is likely due to a defect of the patient's intrinsic factor at the ileal receptor site. Can J Gastroenterol 1989;3(1):34-36 (Pour résumé, voir page 36)
\end{abstract}

Key Words: Alpha thalassemia, Cobalamin deficiency, Dysfunctional intrinsic factor

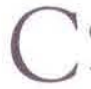

OBALAMIN IS A WATER SOLUBLE vitamin that acts as a cofactor in enzymatic reactions of mammalian cells. Animal products are the only natural dietary source for humans. Intrinsic factor is a glycoprotein (1) which is synthesized by the parietal cells of the stomach; its role in cobalamin absorption was first postulated in 1929 (2). It binds to cobalamin with high affinity in the upper jejunum. The intrinsic factor-cobalamin complex binds to specific receptors on the microvilli of the ileal mucosa (3) and cobalamin is absorbed into the ileal cell.

Genetic defects leading to cobalamin malabsorption are rare causes of megaloblastic anemia during childhood. They usually manifest themselves in the first decade of life. A selective absence of intrinsic factor in the presence of a histologically normal gastric mucosa and normal acid secretion has been recognized since the early 1940s (4). Malabsorption of cobalamin may be caused by
Departments of Medicine and Pathology, University of Ottawa and Ottawa General Hospital, Ottawa, Ontario

Correspondence and reprints: Dr Jeanne Drouin, Division of Hematology, Ottawa General

Hospital, 501 Smyth Road, Ottawa, Ontario KIH 8L6. Telephone (613) 737-8178

Received for publication September 14, 1988. Accepted October 3, 1988 a poorly defined ileal defect as described by Imerslund (5) and Grasbeck (6) or to the presence of a labile intrinsic factor which is degraded by pepsin and acid (7). The fourth and rarest cause of cobalamin deficiency on a genetic basis was reported by Katz et al $(8,9)$ who described a child with defective intrinsic factor with decreased affinity for the ileal receptors and later characterized the defect.

The present authors have studied an adolescent of French Canadian origin in whom anemia due to cobalamin deficiency was also caused by intrinsic factor dysfunction (10).

\section{PATIENT DATA}

An 18-year-old college student was admitted to the Ottawa General Hospital in March 1982 for investigation of normocytic anemia. The patient was the third child of a nonconsanguineous marriage and his parents and three brothers were healthy. He had been well previously except for occasional epigastric burning after meals since early teens. Diet included meat and vegetables daily. The patient had noted progressive weakness and decreased exercise tolerance for about five weeks prior to presentation. On examination he was very pale. There was no scleral icterus or purpura and vital signs were normal. Spleen was palpable 
at $6 \mathrm{~cm}$ below the costal margin, was firm and not tender. The tongue was well papillated and neurological examination was normal.

Hemoglobin was $50 \mathrm{~g} / \mathrm{L}$, mean corpuscular volume $96 \mathrm{fl}$, white blood cell count $3.6 \times 10^{\%} / \mathrm{L}$ with a normal differential count and platelet count was $236 \times 10 \% / \mathrm{L}$. The reticulocyte count was $2 \times 10 \% / \mathrm{L}$ and the blood film showed anisocytosis, schistocytes and some hypersegmented neutrophils. A bone marrow aspirate showed megaloblastic changes and increased iron stores but no ring sideroblasts. Serum lactic dehydrogenase was increased at $1960 \mathrm{iu} / \mathrm{L}$ (normal 100 to $225 \mathrm{iu} / \mathrm{L}$ ) whereas total serum bilirubin level, alanine aminotransferase, aspartate aminotransferase and serum alkaline phosphatase were normal. The serum folate was 3.8 (nor$\mathrm{mal} 2$ to $14 \mathrm{ng} / \mathrm{mL}$ ) and the erythrocyte folate was greater than $1000 \mathrm{ng} / \mathrm{mL}$. Serum cobalamin level was less than 50 $\mathrm{pg} / \mathrm{mL}$ (normal 170 to $750 \mathrm{pg} / \mathrm{mL}$ ). Baseline gastric acid production was normal and the patient had a normal response to pentagastrin stimulation.

A gastric biopsy showed no atrophic changes whereas biopsies of the duodenal mucosa showed mild lymphangiectasia of some villi. Radiological studies of the upper gastrointestinal tract and small intestine showed no abnormality. Serum albumin, calcium and phosphorus levels were normal. Ova and parasites were not found in the stools. A $24 \mathrm{~h}$ urine collection showed no proteinuria.

Following initiation of parenteral cobalamin therapy, there was a prompt reticulocytosis and the hemoglobin value doubled within three weeks. Further studies were carried out in order to determine the cause of cobalamin deficiency.

\section{MATERIALS AND METHODS}

Serum studies: Serum cobalamin and folate and red cell folate determinations were performed using a radioimmunoassay technique according to the manufacturer's instructions (Bio Rad, Richmond, California). Blocking antibody to intrinsic factor was measured by the albumin-charcoal method of Gottlieb et al (11).

Schilling test: Cobalamin absorption was measured using simultaneously administered ${ }^{5} \mathrm{Co}$-labelled vitamin B12 and ${ }^{57}$ Co-labelled vitamin B12 bound to hog intrinsic factor (12) given orally after injection of $1000 \mu \mathrm{g}$ of unlabelled cobalamin. The amount of each radioisotope was measured in the urine collected over $24 \mathrm{~h}$.

Gastric juice studies: Gastric juice was obtained from the patient by nasogastric suction following the injection of $330 \mu \mathrm{g}$ of pentagastrin, was depepsinized (13) and stored at $-20^{\circ} \mathrm{C}$. In order to exclude the presence of labile intrinsic factor, a second collection of gastric juice was carried out with the $\mathrm{pH}$ kept constant at 5.5 by infusing $0.3 \mathrm{~N}$ sodium bicarbonate in the patient's stomach using a double lumen nasogastric tube. Continuous low suction of gastric juice was carried out through the other lumen.

The quantity of intrinsic factor in the gastric juice was determined by the albumin-charcoal method of Gottlieb and colleagues (11). The ability of the patient's intrinsic factor to bind cobalamin was assessed by incubating gastric juice from the patient with radiolabelled cobalamin at $37^{\circ} \mathrm{C}$ and adding an excess of nonradioactive cobalamin. The amount of protein-bound radiolabelled cobalamin was determined at intervals in aliquots of the reaction mixture (11) and the dissociation pattern of the intrinsic factor/radiolabelled cobalamin complex with gradual uptake of unlabelled cobalamin was compared to that of a normal control. Activity of intrinsic factor was measured by the uptake of ${ }^{57}$ Co-labelled vitamin B12 by guinea pig intestinal mucosal homogenate as described by Sullivan and co-workers (14)

\section{TABLE 1}

Hematological parameters, cobalamin levels and Schilling test results in the patient and in members of his family

\begin{tabular}{|c|c|c|c|c|c|}
\hline & \multirow{2}{*}{$\begin{array}{l}\text { Hemoglobin } \\
\mathrm{g} / \mathrm{L}\end{array}$} & \multirow{2}{*}{$\begin{array}{c}\text { MCV } \\
\mathrm{fl}\end{array}$} & \multirow{2}{*}{$\begin{array}{l}\text { Serum cobalamin } \\
\qquad \mathrm{pg} / \mathrm{mL}\end{array}$} & \multicolumn{2}{|c|}{ Schilling test ${ }^{\star}$} \\
\hline & & & & Without IF & With IF \\
\hline Normal & $126-166$ & $83-103$ & $170-750$ & $10-40 \%$ & $10-42 \%$ \\
\hline Patient & 50 & 96 & $<50$ & $6 \%$ & $13 \%$ \\
\hline \multirow[t]{2}{*}{ Parents } & 120 & 71.5 & 145 & $14 \%$ & $17 \%$ \\
\hline & 142 & 86 & 296 & $28 \%$ & $30 \%$ \\
\hline \multirow[t]{3}{*}{ Siblings } & 141 & 83 & 287 & - & - \\
\hline & 153 & 86 & 636 & $31 \%$ & $32 \%$ \\
\hline & 150 & 83.2 & 314 & - & - \\
\hline
\end{tabular}

MCV Mean corpuscular volume: If Intrinsic factor ${ }^{*}$ Urinary excretion of radiolabelled cobalamiri ove $24 h$
Serum studies: At presentation, serum cobalamin was markedly depressed, serum folate was normal and red cell folate was increased (Table 1). Antiintrinsic factor antibodies were not detected.

Schilling test: With the patient in remission, there was a correction of the malabsorption of vitamin B12 with the help of exogenous intrinsic factor, thus pointing to an intrinsic factor defect (Table 1).

Gastric juice studies: The concentration of intrinsic factor was normal at 37 $\mathrm{ng} / \mathrm{mL}$ of gastric juice. Patient intrinsic factor was found to bind cobalamin normally at $48 \mathrm{ng} / \mathrm{mL}$ indicating that there was no abnormality at the cobalamin binding site.

The patient's gastric juice did not promote uptake of radiolabelled cobalamin by guinea pig mucosa homogenates, thus suggesting an abnormality of the intrinsic factor at the ileal receptor binding site.

Assays performed on gastric juice collected at pH 5.5 showed comparable results to the above and excluded the presence of a labile intrinsic factor.

Family study: Review of the family pedigree over four generations revealed no consanguinity of the parents and no relation with the index case. HLA typing studies failed to show common haplotypes for the two parents.

Serum folate levels were normal in all family members. The hematological parameters, cobalamin levels and Schilling test results were as shown in Table 1. In view of the microcytic anemia, further work-up was done in the patient's father. Electrophoresis of his hemoglo- 
bin was normal and a search for hemoglobin $\mathrm{H}$ in his red cells was negative. $\mathrm{A}$ bone marrow aspirate showed normal cellular morphology and iron stores. Gene mapping analysis showed deletions of two $\propto$-hemoglobingenes in a transconfiguration in the father and of a single $\propto$-hemoglobin gene in the patient.

\section{DISCUSSION}

The present patient presented in late adolescence with severe cobalamin deficiency which appeared to be secondary to a dysfunctional intrinsic factor as previously reported in another unrelated patient (8). Classical pernicious anemia was ruled out by the presence of a normal gastric mucosa on biopsy and preservation of gastric acidity. Generalized malabsorption was excluded by the normal radiologic and biochemical studies, and selective malabsorption of cobalamin $(5,6)$ was ruled out by the absence of proteinuria in a $24 \mathrm{~h}$ urine collection. Selective absence of intrinsic factor was excluded by the finding of normal amounts of intrinsic factor in gastric juice. It was also found that the patient's intrinsic factor could bind cobalamin normally. However, data derived from the Schilling test and studies using guinea pig intestinal mucosal homogenates indicated that the intrinsic factor did not attach normally to the ileal receptor sites and thus could not promote cobalamin absorption. A labile intrinsic factor was ruled out when similar results were obtained using gastric juice collected from the patient at a less acidic $\mathrm{pH}$ in order to avoid acid-pepsin degradation (7).

In contrast to the index case, there was no consanguinity of the parents as evidenced by history and HLA typing. Also, by history, this family was not related to the family of the first patient who is also of French Canadian origin. Thus, in the present patient, the genetic disorder could be different from that of the first reported case; the older age of presentation suggests that the defect is a milder one.

The absence of florid macrocytosis of the patient's red cells while serum cobalamin was markedly depressed at presentation prompted further hematological studies in this family. This led to the dis- covery of $\propto$-thalassemia, the father having two and the patient a single $\propto$-hemoglobin gene deletion. These findings explain the father's mild microcytic anemia and the patient's normal mean red cell volume at presentation while he was severely cobalamin deficient.

It is of interest that the present patient presented with two genetic disorders simultaneously. Data regarding the prevalence of $\propto$-thalassemia in French Canadians or in French populations are not available; it is probably very low as has been observed in British people (15). Nevertheless, it appears likely that the two genetic defects that were observed in this family arose in a totally independent manner.

ACKNOWLEDGEMENTS: We thank Dr M. Katz for the intrinsic factor studies, Dr M. Ali for the DNA analysis and Dr C. Hetenyi and her staff for collecting the gastric juice for these studies.

\section{REFERENCES}

1. Allen RH. Human vitamin B12 transport proteins. Prog Hematol 1975; 9:57-84.

2. Castle WB, Townsend WC. Observations on the etiologic relationship of achylia gastrica to pernicious anemia. II. The effect of the administration to patients with pernicious anemia of beef muscle after incubation with normal human gastric juice. Am J Med Sci $1929 ; 178: 764-77$

3. Donaldson RM Jr, Mackenzie IL, Trier JS. Intrinsic factor-mediated attachment of vitamin B12 to brush borders and microvillous membranes of hamster intestine. J Clin Invest 1967; $46: 1215-28$

\section{La malabsorption de cobalamine attribuable à un dysfonctionnement du facteur intrinsèque}

Le patient est un étudiant franco-canadien de 18 ans qui présente une anémie normocytaire grave et un taux indétectable de cobalamine sérique; par ailleurs, l'acidité gastrique est normale et il n'existe aucun indice de malabsorption généralisée. Les jus gastriques contiennent une quantité normale de facteur intrinsèque. Les anticorps bloquants anti-facteur intrinsèque sériques ne sont pas présents. Labsorption de cobalamine sérique administrée par voie orale au cours du test de Schilling a été freinée mais la diminution a été corrigée avec du facteur intrinsèque de porc. Les jus gastriques du patients captent normalement la cobalamine sérique mais la fixation de la vitamine en question n'est pas favorisée par les homogénats de muqueuse intestinale de cochon d'inde. L'examen auquel a été soumis toute la famille montre une absorption normale de cobalamine sérique pour tous les sujets testés, ainsi qu'une délétion du gène Alpha 2 chez le père et une délétion du gène alpha simple chez le patient. La malabsorption de cobalamine sérique chez le patient est probablement attribuable à une insuffisance du facteur intrinsèque au niveau du récepteur iléal. 


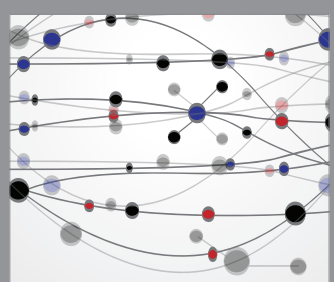

The Scientific World Journal
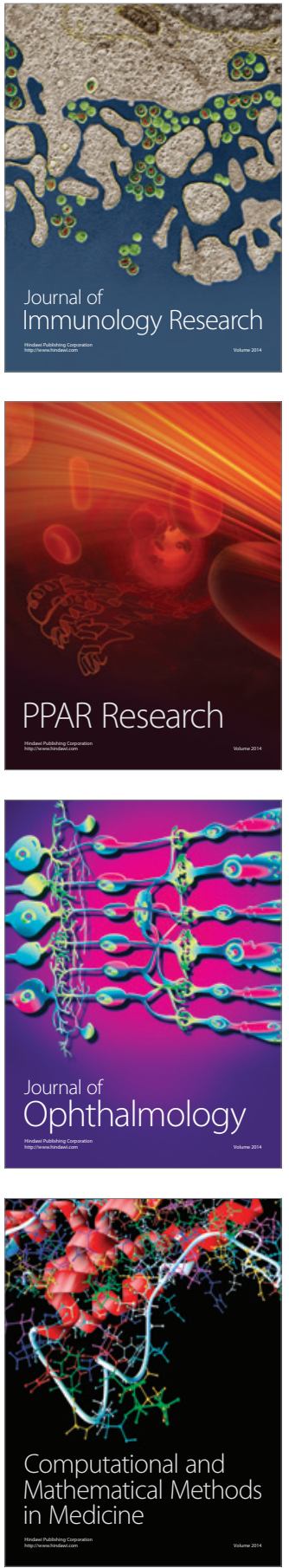

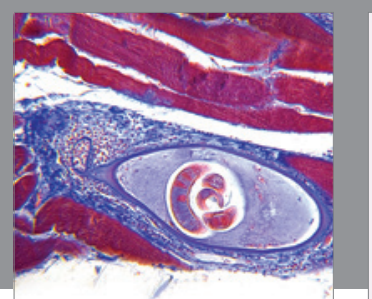

Gastroenterology Research and Practice

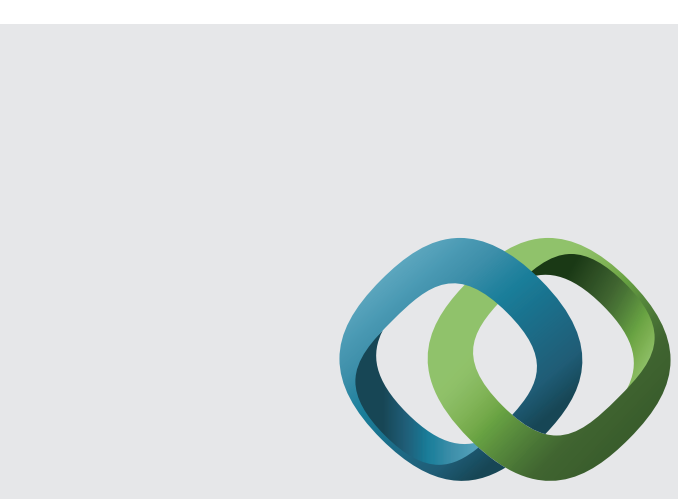

\section{Hindawi}

Submit your manuscripts at

http://www.hindawi.com
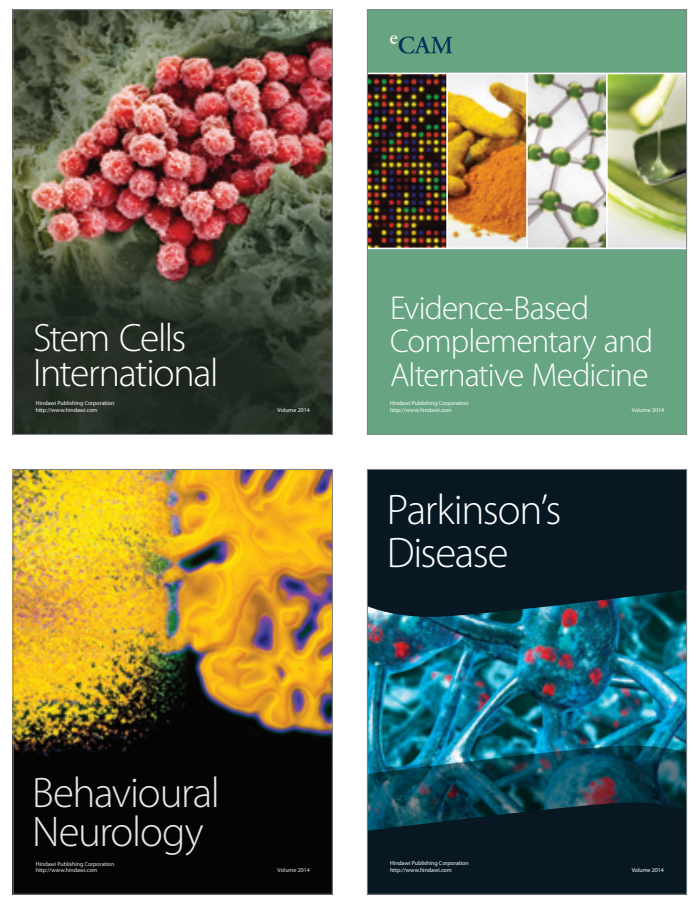
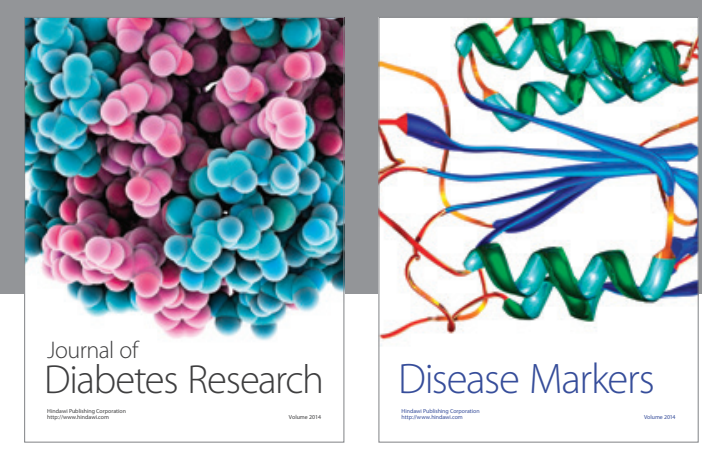

Disease Markers
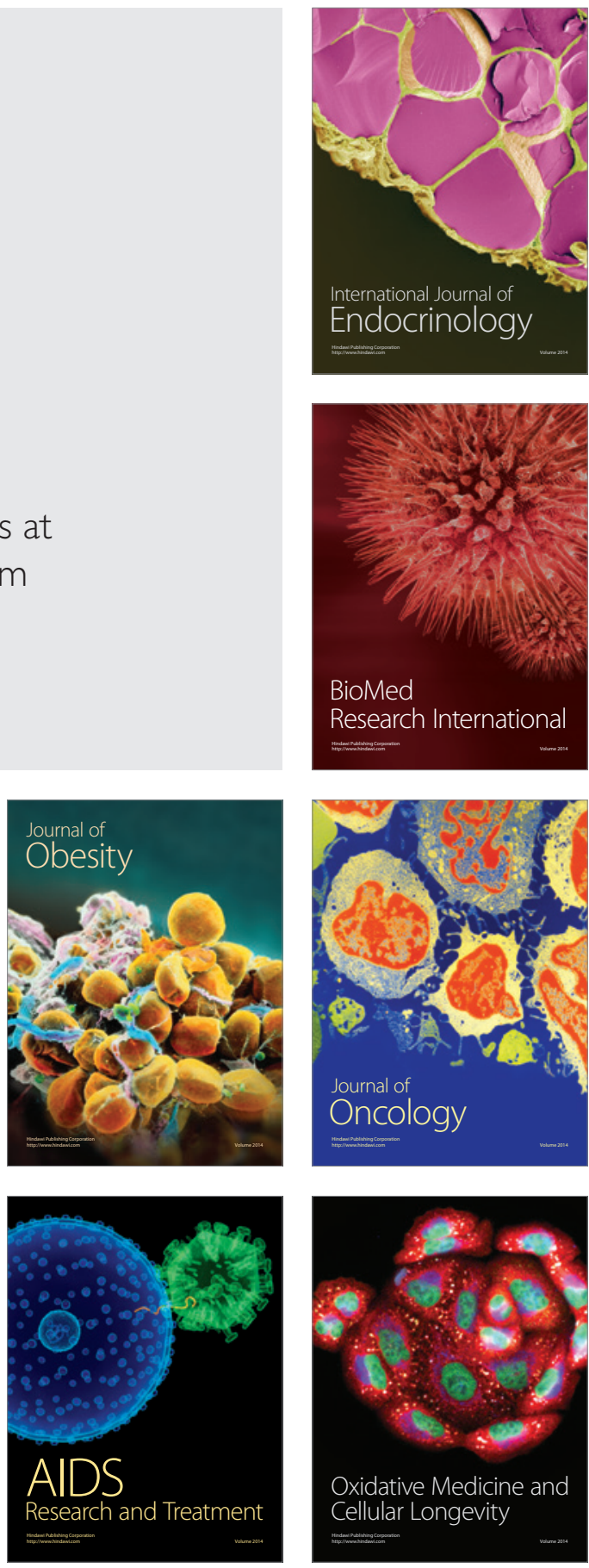